\title{
Estimation the level of il-17a in a sample of type i diabetes mellitus patients
}

\author{
${ }^{1,}$ Amani Mahmood Tuama (MsC), ${ }^{2,}$ Hiba Abid Al-Hussein Hassan (MsC), \\ ${ }^{3,}$ Khaleel Ibrahim Rashid (PhD) \\ 1, 2, 3, Collage of Health and Medical Technology/Baghdad
}

\begin{abstract}
Type 1 diabetes mellitus (T1 DM) is a chronic autoimmune disease associated with selective destruction of insulin-producing pancreatic $\boldsymbol{\beta}$-cells. Several features characterize type 1 DM as an autoimmune disease: presence of immuno-competent and accessory cells infiltrated pancreatic islets. This is a prospective study which was carried out to investigate the possible association of T1 DM with IL-17A.

Sixty patients with Type 1 diabetes mellitus (T1 DM) who were diagnosed according to American Diabetes Association criteria (ADA) 1997 were selected from the Center of Endocrinology and Diabetes /ALKindey / Hospital/Baghdad. All patients were treated with daily replacement doses of insulin. Their age ranged 5- 40 years. As a control group, sixty apparently healthy volunteers whose their age (8-40) years, and sex (Females: Males 1:1.31) were matched the patients' group. The study revealed that the high frequencies of T1 DM was at the age group 10-19 years while the lower frequency among age group <10 years old.
\end{abstract}

Regarding cytokine level, it was noticed that there was highly significant elevation in the mean of IL$17 \mathrm{~A}$ in the sera of diabetic group $(1312.06 \mathrm{Pg} / \mathrm{ml})$ in comparison with healthy control $(332.28 \mathrm{pg} / \mathrm{ml})$ $(P=0.003)$.

Conclusion, there appears to be an important role for IL-17A in increasing the chance of enhancing the susceptibility for disease development or providing protection against it.

KEY WORDS: Diabetes mellitus, IL-7A, ELISA

\section{INTRODUCTION}

Diabetes mellitus (DM) is a heterogeneous group of metabolic diseases characterized by hyperglycemia resulting from defects in insulin secretion, insulin action, or both. [1]. It was reported that Type 1D is caused by a deficiency in insulin secretion due to the loss of pancreatic $\beta$ cells, and the disease requires life-long treatment with exogenous insulin. Without the body's own insulin production the body loses its ability to utilize carbohydrates as an energy source. Type 1D M is considered as an autoimmune disease, which is developed due to the T-cell-mediated destruction of $\beta$ cells in the islets of Langerhans of the pancreas. In children with an active $\beta$-cell destruction process, autoantibodies against $\beta$-cell structures appear in the circulation [2]. It was observed that this process occurs in genetically susceptible subjects, and it is probably triggered by one or more environmental agents, and usually progresses over many months or years during which the subject is asymptomatic and euglyecemic [3].

The pathogenesis of T1D has been considered to result from a breakdown of immunologic tolerance towards $\beta$-cell antigens. Immunologic tolerance is maintained by two major phenomenon; central and peripheral tolerance. Peripheral tolerance is dictated by the fine balance between effectors' $\mathrm{T}$ cells and so called regulatory $\mathrm{T}$ cells. Defects in T-cell polarization and immune regulation have been associated with T1D. Recent advances in $\mathrm{T}$ cell research have provided new insights into the dynamics and regulation of $\mathrm{T}$ cell responses. Not only the balance between fully committed effectors' $\mathrm{T}$ cells and regulatory $\mathrm{T}$ cells, but also the plasticity between these phenotypes seems to play a role in autoimmunity and tolerance [4],[5].

A distinct and separate lineage of Th cells secreting the proinflammatory cytokine IL-17 has been recently described [6]. The discovery of these Th17 cells has had a major impact on our understanding of immune processes not readily explained by the Th1/Th2 paradigm. Th17 cells are intimately involved in promotion of autoimmunity [7]; in particular, rheumatoid arthritis [8], experimental autoimmune encephalomyelitis [9], and multiple sclerosis [10]. Moreover, there is preliminary evidence that IL-17 is expressed in the pancreas in the course of T1D in the murine model of T1D [11, 12]. Two recent articles found that transfer of islet-specific Th17 cells induced diabetes, but only after the cells converted to IFN- $\gamma$ producing cells $[13,14]$. 


\subsection{Patients Group}

\section{MATERIALS AND METHODS}

The study comprised sixty Iraqi Arab Patients (26 females and 34 males) with T 1 DM who was attending the center of Endocrinology and Diabetes/ AL-kindey Teaching Hospital/ Baghdad. All patients were selected on the basis of absolute dependency on insulin according to the revised criteria for diagnosis of DM as defined by the American Diabetes Association (ADA) (1997), The Expert Committee, (1997).

\subsection{Control Group}

Sixty apparently healthy volunteers whose their ethnic back ground, age, and sex were matched the patients group, consisted of unrelated non-diabetic individuals according to the laboratory finding of FPG value $<6 \mathrm{mml} / \mathrm{L}$ which was considered as control. All of them had negative family history of DM with age range was (5-40) years. All investigations were carried out for patients as well as the control group according to the study protocol. Venous blood sample which have been collected from each fasting subject and tested for the serological by enzymatic method (ELISA) and biochemical tests.

\subsection{Methods}

\section{Reagents \& Kits}

A- Micro plate Elisa Kits For the quantitative determination of C- Peptide in human serum or EDTA, heparin or citrate plasma/Germany DRG.

B- Koma Bio Tech micro plate ELISA for the quantitative determination of cytokine in human serum, plasma, culture medium or other biological fluid/Koma BioTech Korea.

C- Fasting Plasma glucose test kit/spin react/Spain.

\subsection{Statistical analysis}

The suitable statistical methods were used in order to assess and analyze our results, by using SPSS version 13 (Statistical Package for Social Sciences).

\section{RESULTS AND DISCUSSION}

\subsection{Demographical Picture of the Studied Groups}

The demographical picture of the studied groups showed that the mean of diabetic patients was $16.32 \pm 0.85$ (SE) years with M:F ration of $1: 1.31$ Family history revealed that $(28.3 \%)$ of diabetic with a previous family history for diabetic as shown in Table 3.1.It s clear from this table that there is a significant difference in fasting plasma glucose level among diabetic patients $(231.97 \pm 14.85 \mathrm{mg} / \mathrm{dL})$ in comparison with apparently healthy control group $(80.57 \pm 1.85 \mathrm{mg} / \mathrm{dL})(\mathrm{P}<0.001)$.

Table 3.1: Demographical picture of the studied groups

\begin{tabular}{|c|c|c|c|c|}
\hline No. & Demographical Parameters & Diabetic Patients & $\begin{array}{l}\text { Healthy } \\
\text { Control }\end{array}$ & $P$ value \\
\hline 1 & Age (years)[Mean \pm SE] & $16.32 \pm 0.85$ & $17.93 \pm 1.20$ & $0.27(\mathrm{NS})$ \\
\hline 2 & $\begin{array}{l}\begin{array}{l}\text { Age of Disease } \\
\text { (Mean) }\end{array} \\
\text { Onset }\end{array}$ & $11.38+5.79$ & - & \\
\hline 3 & Males: Females Ratio & $34: 26=1.31$ & $36: 24=1.5$ & \\
\hline 4 & $\begin{array}{l}\text { Positivity of Family History } \\
{[\mathrm{No}(\%)]}\end{array}$ & $17(28.3 \%)$ & - & \\
\hline 5 & Fasting Plasma Glucose $[\mathrm{mg} / \mathrm{dL}]$ & $231.97 \pm 14.85$ & $80.57 \pm 1.85$ & $<0.001$ \\
\hline & Total number & 60 & 30 & \\
\hline
\end{tabular}

NS: Not Significant

\subsection{Distribution of Patients \& Healthy Control according to Age Groups}

Distribution of patients and control groups according to age groups was listed in Table 4.2. In this table, it appears that most patients (73.33\%) were at age group (10-19 years) no significant difference between this age group and the other groups $(\mathrm{P}=0.27)$. 
Table 3.2: Distribution the diabetic patients and control groups according to age groups

\begin{tabular}{|c|c|c|c|}
\hline Age Groups (Years) & $\begin{array}{c}\text { Diabetic Patients No } \\
(\mathbf{\%})\end{array}$ & Healthy Control & \multirow{2}{*}{ P value } \\
\hline$<10$ & $5(8.33)$ & $2(6.7)$ & \multirow{2}{*}{ P= 0.27 } \\
\hline $10-19$ & $44(73.33)$ & $22(73.3)$ & \\
\hline $20-29$ & $7(11.67)$ & $4(13.3)$ & \\
\hline$\geq 30$ & $4(6.67)$ & $2(6.7)$ & \\
\hline Total & $60(100.0)$ & $30(100.0)$ & \\
\hline
\end{tabular}

\subsection{Level of Fasting Plasma Glucose among the Studied Groups:}

The level of fasting plasma glucose was highly significantly altered among the patient's group in comparison with control group as shown in Table 3.3.

Table 3.3: Levels of FPG among diabetic and control group

\begin{tabular}{|c|c|c|}
\hline \multirow{2}{*}{} & \multicolumn{2}{|c|}{ (FPG)mg/Dl } \\
\cline { 2 - 3 } & Study & Control \\
\hline N & 60 & 30 \\
\hline Minimum & 34.2 & 60 \\
\hline Maximum & 491.4 & 99 \\
\hline Mean & 231.974 & $\mathbf{8 0 . 5 6 6 7}$ \\
\hline Std. Error & 14.8502 & 1.8462 \\
\hline Std. Deviation & 115.029 & 10.1121 \\
\hline C.S. & \multicolumn{2}{|c|}{ t=10.118 : P<0.001 } \\
\hline \multicolumn{2}{|c|}{ HS } \\
\hline
\end{tabular}

\section{4: Estimation of IL-17A in the Sera of Diabetic Patients and Healthy Control Groups}

Quantitation of IL-17A level in the sera of the studied groups revealed that there was highly significant difference between its level among patients $(1312.06 \pm 697.03 \mathrm{pg} / \mathrm{ml})$ in comparison with control group $332.8 \pm 256.769 \mathrm{pg} / \mathrm{ml})(\mathrm{P}=0.003)$. These data are represented in Table 3.4 .

Table 3.4: Comparison of Interleukins -17A Level among the studied groups

\begin{tabular}{|c|c|c|c|}
\hline \multirow{2}{*}{ Statistic Values } & \multicolumn{2}{|c|}{ IL-17 A Pg/ ml } & \multirow{2}{*}{ P value } \\
\cline { 2 - 3 } & Diabetic Patients & Healthy control & \\
\hline Mean & 1312.06 & 332.8 & \\
\hline Standard Error & 697.03 & 256.769 & \multirow{2}{*}{ P=0.003 HS } \\
\hline Median & 1322 & 226 & \\
\hline Maximum & 3567 & 1116.4 & \\
\hline Minimum & 230 & 905 & \\
\hline Range & 3336.0 & 100 & \\
\hline Interquantile Range & 790.0 & 359.96 & \\
\hline Geometric Mean & 552.95 & &
\end{tabular}

\section{DISCUSSION}

Sixty Iraqi Arab, diabetic patient (34 males and 26 females) were selected for this study with age ranged from (5-40) years. The highest incidence (73.33\%) observed under the age group (10-19) years. This finding is in agreement with other Iraqi studies such as $[14,15,16,17]$ and with abroad studies $[18,19]$ who reported that the age of puberty represents the higher risk of developing T1DM than other age group. But this study disagrees with other Iraqi studies [20, 21]

To focus on sex variable of the studied group, this study revealed that the ratio of male: female in the patient group was 1:1.31 which is compatible with Iraqi studies [18, 20, 22, 23] and abroad studies reported by [24]. On the contrary, they incompatible with Iraqi studies [14, 18] and abroad studies [25, 26].

Statistically studied showed the level of IL-17A in patients group was elevated in comparisons with healthy group (1312 vs.332.8 pg /ml, P 0.003), which is agreement with a broad study [27,28].The explanation of this increased may possibly related to hyperglycemic state of diabetic subject which could induced the secretion of these cytokines by monocytes [28]. 


\section{REFERENCES}

[1]. Report of the expert committee on the diagnosis and classification of diabetes mellitus. Diabetes Care; (2003); 26 Suppl 1: S5-20.

[2]. $\quad$ Rosenbloom AL, Joe JR, Young RS. \& Winter WE. "Emerging epidemic of type 2 diabetes in youth." Diabetes Care (1999); 22: 345-354.

[3]. Akerblom HK, Vaarala O. \& Hyoty H. "Environmental factors in the etiology of type 1 diabetes." Am. J. M. Gene. (2002); 115: 18-29.

[4]. Bending D, De La Pena H, Veldhoen M, Phillips JM, Uyttenhove C, Stockinger B. \& Cooke A. "Highly purified Th 17 cells from BDC2.5NOD mice convert into Th 1-like cells in NOD/ SCID recipient mice." J. Clin. Invest. (2009).

[5]. Zhou, X, Bailey-Bucktrout SL, Jeker LT, Penaranda C, Martinez- Llordella M, Ashby M, Nakayama M, Rosenthal W. \& Bluestone JA. "Instability of the transcription factor Foxp3 leads to the generation of pathogenic memory T cells in vivo." Nat. Immunol. (2009); 10: 1000-1007.

[6]. Harrington LE, Hatton RD, Mangan PR, Turner H, Murphy TL, K. M. Murphy, \& Weaver CT. "Interleukin 17-producing CD4_ effector T cells develop via a lineage distinct from the T helper type 1 and 2 lineages." Nat. Immunol. (2005); 6: 1123-1132.

[7]. Steinman L. "A brief history of TH17, the first major revision in the TH1/ TH2 hypothesis of T cell-mediated tissue damage." Nat. Med. (2007); 13: 139-145.

[8]. Chen Y, Blumenschein WM, Murphy CA, Langrish CL, Mc-Clanahan TK, Kastelein RA, Sedgwick JD, \& Cua DJ. "Divergent pro- and anti-inflammatory roles for IL-23 and IL-12 in joint autoimmune inflammation." (2003); J. Exp. Med. 198: $1951-57$.

[9]. Cua D, Sherlock J, Chen Y, Murphy C, Joyce B, Seymour B, Lucian L, To W, Kwan S, Churakova T, et al.. "Interleukin-23 rather than interleukin- 12 is the critical cytokine for autoimmune inflammation of the brain." Nature; (2003); 421: 744-748.

[10]. Tzartos JS, Friese MA, Craner MJ, Palace J, Newcombe J, Esiri MM, \& Fugger L. "Interleukin-17 production in central nervous system-infiltrating T cells and glial cells is associated with active disease in multiple sclerosis." Am. J. Pathol. (2008); 172: 146155 .

[11]. Vukkadapu SS, Belli JM, Ishii K, Jegga AG, Hutton JJ, Aronow BJ. \& Katz JD. "Dynamic interaction between T cell-mediatedcell damage and -cell repair in the run up to autoimmune diabetes of the NOD mouse." Physiol. Genomics; (2005); 14: 201-211.

[12]. Jain R, D. M. Tartar DM, R. K. Gregg RK, R. D. Divekar RD, Bell JJ, Lee HH, Yu P, Ellis JS, Hoeman CM, Franklin CL, \& Zaghouani H. "Innocuous IFN-induced by adjuvant-free antigen restores normoglycemia in NOD mice through inhibition of IL-17 production." J. Exp. Med. (2008); 205: 207-218.

[13]. Martin-Orozco N, Chung Y, Chang SH, Wang YH, \& Dong C. "Th17 cells promote pancreatic inflammation but only induce diabetes efficiently in lymphopenic hosts after conversion into Th1 cells." Eur. J. Immunol. (2009); 39: $216-224$.

[14]. AL-Ramahi, N.R.A "Genotyping of HLA Class-II Molecules and its correlation with Some Immunological Parameter in Type 1 Iraqi diabetic patients. A thesis submitted to the College of Medicine / Baghdad University for the partial fulfillment PhD degree in Medical Microbiology /Immunology (2009).

[15]. Barsoon HYH. "Clinical and immunological study in patients with insulin dependent diabetes mellitus." A thesis submitted to the College of Medicine /Baghdad University, for M.Sc.in Microbiology (1994).

[16]. Hasso MGN. " Possible monitors of active beta cell damage in high risk group of insulin dependent diabetes mellitus." A thesis submitted to the College of Medicine /Baghdad University, for M.Sc. (1995).

[17]. Dawood SW "Screening for autoantibodies and viral antibodies in Diabetes Mellitus. A thesis submitted to the College of Medicine /Baghdad University, for M.Sc. In Microbiology (1998)

[18]. Abdullah MA. "Epidemiology of type 1 diabetes mellitus among Arab children." Saudi. Med. J. (2005); 26(6):911-917.

[19]. Weets I, Rooman R, Coeckelberghs M, et al., "The age at diagnosis of type 1 diabetes continues to decrease in Belgian boys but not in girls: a 15-year survey." Diabetes Metab. Res. Rev. (2007); 23(8):637-43.

[20]. Salih DH "Dyslipidemia in type 1 diabetic Iraqi patients." A thesis submitted to the College of Health \& Medical Technology/ Foundation of Technical Institute, for M.T. In Medical laboratory science technology (2008).

[21]. Mahmood TD "Autoantibodies to Glutamic acid decarboxylase. Tyrosine phosphatase and Insulin in Iraqi type 1 diabetic patients." A thesis submitted to the College of Medicine /Baghdad University, for degree of fellowship of the Iraqi commission, (2008b).

[22]. Al-Khayali HG. "A clinico-Epidemiological study of insulin dependent diabetes mellitus in children and adolescents." A thesis submitted to the College of Medicine /Baghdad University, for M.Sc. (1993).

[23]. Ali JA. "Investigation of Selected Immnunological Marker In First Degree Relatives of Type 1 Diabetic Patients." A thesis submitted to the College of Health and Medical Technology. In Immunology (2010)

[24]. Kawabata Y, Ikegami H, Kawaguchi Y, et al., "Asian-Specific HLA Haplotypes Reveal Heterogeneity of the Contribution of HLA-DR and -DQ Haplotypes to Susceptibility to Type 1 Diabetes." Diabetes (2002); 51: 545-51.

[25]. Shaltout AA, Moussa MA, Qabazard M, et al., "Further evidence for the rising incidence of childhood Type 1 diabetes in Kuwait. Diabet. Med. (2002); 19(6): 522-5.

[26]. Harjutsalo V, Sioberg L, Tuomilehto J. "Time trends in the incidence of type 1 diabetes in Finnish children: a cohort study. Lancet. (2008); 24; 371 (9626) :1730-1.

[27]. Bradshaw EM, Raddassi K, Elyaman W, Orban T, Gottlieb PA, Kent SC. \& Hafler DA. "Monocytes from Patients with Type 1 Diabetes Spontaneously Secrete Proinflammatory Cytokines Inducing Th17 Cells1." J. Immunol. (2010); 183; 4433-39

[28]. Honkanen J. "Studies of Immune Regulation in Type 1 diabetes" Academic dissertation for PhD, Faculty of Medicine/ University of Helsinki. (2010). 